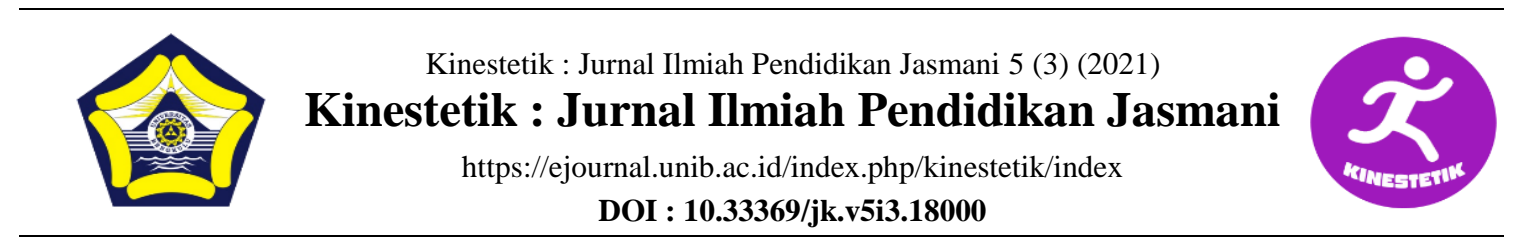

\title{
EVALUATION OF THE IMPLEMENTATION OF 2013 CURRICULUM VOCATIONAL BATUBARA REGENCY
} \section{Indonesia \\ Article Info \\ Article History : \\ Received : September 2021 \\ Revised : September 2021 \\ Accepted : September 2021 \\ Available online : September 2021}

Albadi Sinulingga ${ }^{1 *}$, Sanusi Hasibuan ${ }^{2}$, Mauluddin M. Noor ${ }^{3}$

${ }^{123}$ Sports Education, Faculty of Sports Science Universitas Negeri Medan, Sumatera Utara,

Keywords:

Evaluation, 2013 Curriculum, Batubara

\section{Abstract}

This research aims to evaluate the implementation of the 2013 Curriculum in Batubara District. The components of curriculum implementation that are evaluated include: (1) student conditions, (2) teacher conditions, (3) teacher understanding of the curriculum, (4) conditions of infrastructure, (5) lesson planning, (6) implementation of scientific-based learning, (7) ) implementation of authentic assessments, and (8) authentic assessment results related to aspects of attitudes, knowledge and skills. The evaluation model used is the Model evaluation model Stake Countenance by collecting information on curriculum implementation component data and then comparing it with the standards of the ministry of education. The population consists of 13 SMK. The research subjects were principals and teachers who were determined by purposive sampling technique. The instruments used were questionnaire sheets, observation sheets, and documentation sheets. The trial of the questionnaire instrument was conducted at a vocational school in Batubara district. Data analysis using descriptive techniques. The results of the study, the condition of the students was $93.4 \%$, the condition of the teacher was $75 \%$, the condition of the infrastructure was $69.3 \%$, the understanding of the 2013 curriculum was $80 \%$, the lesson planning or RPP was $75 \%$, the implementation of learning was $95 \%$, the implementation $90 \%$ authentic assessment, $82.5 \%$ authentic assessment results. Based on the results of the study, it can be concluded that all aspects in each stage have not been fulfilled maximally according to the standard.
Corresponding address : Di Jl. William Iskandar Ps. V Kenangan

Baru Kec. Percut Sei Tuan Kabupaten Deli Serdang, Sumatra Utara

*Corresponding email : badisling@hotmail.com

\author{
ISSN 2685-6514 (Online) \\ ISSN 2477-331X (Print)
}




\section{INTRODUCTION}

In improving the quality of education in Indonesia, various efforts have been made by the government and educational institutions. These efforts are marked by changes in the curriculum and learning models carried out by education managers and education practitioners. This is done so that learning can run according to the characteristics of students so that it can produce competent human resources (Hardman, 2013) and in accordance with the expectations of development in Indonesia. "Curriculum development in 2013 is part of a strategy to improve educational attainment. So that the development of the quality of human resources can be done by implementing the 2013 curriculum in learning"(Majid, 2014: 27).

Batubara Regency, the 2013/2014 academic year is the first year that the new curriculum is implemented, namely the 2013 Curriculum. The implementation of the 2013 Curriculum is still limited because it has only been implemented in schools. Expectations from the government, in the academic year 2014/2015, levels and Vocational High School has been implementing Curriculum 2013. So all levels of education are already implementing the curriculum in 2013, and already has graduated with Curriculum 2013.

Its implementation has been continuous and is still performed in FY 2018 / 2019. In the early stages of the research, researchers conducted interviews with PJOK teachers at SMK in Batubara Regency and the principal as the implementation of the 2013 curriculum. The results of these interviews were also summarized in the 2013 Curriculum Assistance Evaluation Meeting for School Principals in Batubara Regency and found several problems that It is felt that there are still obstacles in implementing the 2013 curriculum, including in the preparation, implementation, and evaluation / assessment stages. In the preparation stage, not all PJOK teachers are skilled in operating IT, which hinders the smooth implementation of tasks such as making lesson plans, processing grades, using multimedia learning media, and others. The PJOK textbooks Students in class XI arrive at school that take quite a long time, and the books used are in Pdf form. The learning material in student books and teacher books is very minimal so it must use relevant companion books.

PJOK teachers also experience problems in implementation, including class XI students who find it difficult to be active in learning due to the long facilities arriving. Meanwhile, based on the opinion of PJOK teachers implementing the 2013 Curriculum (2013 Curriculum Assistance Evaluation Meeting for School Principals of Batubara Regency, 2013), the material in Student Textbooks demands mastery of the material and independent learning. Another obstacle is that the implementation of learning cannot be completed in one meeting or one day because of the large number of activities that must be carried out by PJOK teachers and students. In learning the teacher carries out authentic assessments for every aspect, and students complete dense learning activities. Obstacles in the evaluation / assessment phase faced by teachers include the authentic assessment system that cannot be carried out optimally by PJOK teachers considering the large number of students and the large number of assessment elements. This includes setting up a list of values, book reports on learning outcomes (raport). The teacher does not understand the assessment guidelines so that it is difficult to make UTS / UAS questions in revealing what 
aspects of knowledge refer to the teaching material.

Obstacles that exist in the initial implementation stage of the 2013 Curriculum should be explored in-depth immediately to find the most possible solution. From the results of the evaluation of the 2013 Curriculum implementation team in the first year that there were still obstacles / obstacles, the researcher wanted to know whether after the implementation of the 2013 curriculum in vocational schools and having produced graduates there were still obstacles / obstacles in the implementation and to what extent the implementation of the 2013 curriculum was seen from various aspects such as the condition of students, the condition of PJOK teachers, the conditions of sports infrastructure, the preparation of PJOK learning planning, the implementation of PJOK learning, and the assessment of PJOK learning. Therefore an evaluation will be carried out.

\section{METHODS}

An overview of the implementation of the 2013 SMK curriculum evaluation in Batubara Regency can be obtained by a research model with a series of implementation starting from the beginning to the comparison process as follows:

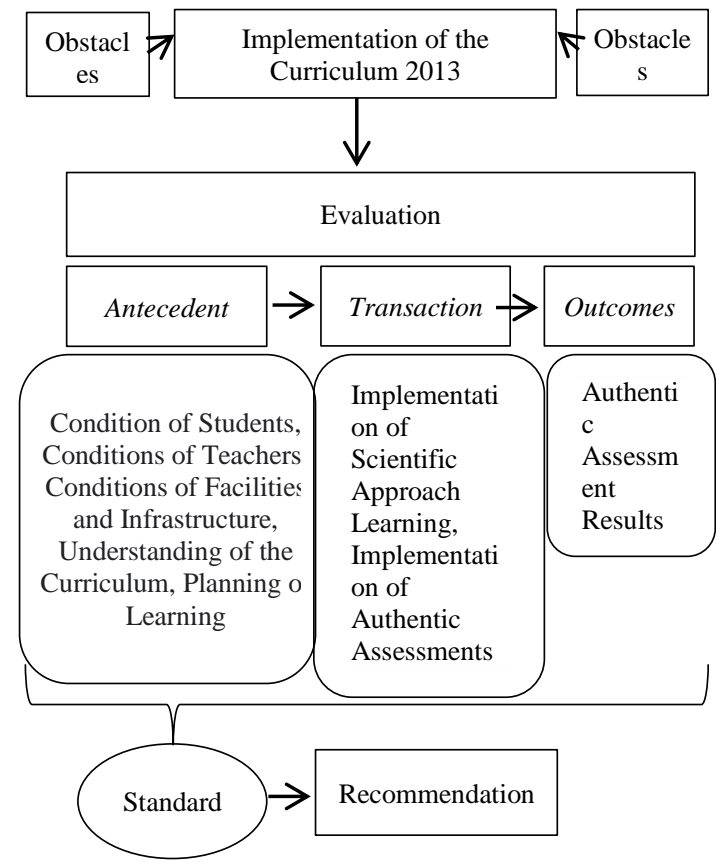

Figure 1. Schematic of the 2013 Vocational School Curriculum Implementation Evaluation Stages in Batubara Regency in 2018/2019 The

Data collection technique uses non-test techniques by using a questionnaire technique using a rating scale with a scale range of 1-4, learning planning observations (RPP) made by the teacher; thestage transaction (process), namely the learning process with a scientific approach related to teacher and student activities during learning to determine the implementation of lesson plans and the implementation of authentic assessments; and the stage, outcomes namely observations related to authentic assessment results, and documents related to school profiles, list of student scores, student attendance lists, teaching planning / lesson plans made by teachers, forms and types of learning evaluation, and assessment results (list of scores). 
The data analysis technique used is the data analysis technique according to the Stake model, namely by comparing the results obtained data with predetermined criteria. Researchers describe conditions, activities with descriptions of quantitative data. The research data in the form of a questionnaire added up to obtain a total score. Then the total score is calculated descriptively using the score obtained (in\%) with the percentage descriptive analysis matched with the criteria table for questionnaire processing using the following criteria from Djemari Mardapi (2008):

Table 1. Descriptive Analysis Criteria Levels The following percentages:

\begin{tabular}{ccc}
\hline No & Percentage & Criteria \\
\hline 1 & $80,01 \%-100 \%$ & Very good \\
\hline 2 & $60,01 \%-80 \%$ & Good \\
\hline 3 & $40,01 \%-60 \%$ & Less \\
\hline 4 & $0 \%-40 \%$ & Poor \\
\hline
\end{tabular}

The next step is to give consideration to the program under study, based on the applicable standards. From the results of these considerations, feedback can be given to policy makers. The success criteria are used to see the extent to which the 2013 curriculum has been successfully implemented based on the criteria that have been made. The 2013 curriculum implementation evaluation criteria are attached in the appendix. As for the success criteria for each aspect, namely:

Table 2. Criteria for the success of implementing the 2013 curriculum.

\begin{tabular}{cll}
\hline $\begin{array}{c}\text { Stage } \\
\text { of }\end{array}$ & \multicolumn{1}{c}{ Aspect } & $\begin{array}{c}\text { Criteria for } \\
\text { Success }\end{array}$ \\
\hline Prelimi & $\begin{array}{l}\text { Student conditions; } \\
\text { nary }\end{array}$ & Teacher conditions; \\
(Antece & Teacher & \\
dent) & $\begin{array}{l}\text { understanding of } \\
\text { the curriculum; }\end{array}$ & $100 \%$ \\
& $\begin{array}{l}\text { Conditions for } \\
\text { infrastructure; }\end{array}$ & \\
& Learning planning. & \\
&
\end{tabular}

\begin{tabular}{clc}
\hline $\begin{array}{c}\text { Process } \\
\text { (Transa } \\
\text { ction) }\end{array}$ & $\begin{array}{l}\text { Implementation of } \\
\text { learning }\end{array}$ & $100 \%$ \\
\hline $\begin{array}{c}\text { Results } \\
\text { (Outco } \\
\text { mes) }\end{array}$ & $\begin{array}{l}\text { Implementation and } \\
\text { assessment. }\end{array}$ & \\
\hline
\end{tabular}

To enhance the chances of obtaining credible findings the researcher takes through triangulation. Meanwhile, as a complement, peer discussion techniques (reviewing / peer debriefing) and checking on the adequacy of references (referential adequacy checks) are also used. Thus, to obtain valid data, this study used the recommended technique; Moleong (2007: 330); Creswell (1998); and Nasution (2003), namely: triangulation (triangulation) of data sources and methods.

\section{Participants}

Research subjects in the 2013 curriculum evaluation were carried out on PJOK teachers, students, school principals and the process of implementing the 2013 PJOK SMK curriculum in Batubara Regency for the 2018/2019 academic year. A total of 13 SMK in Batubara District implemented the 2013 curriculum with 13 school principals, 20 PJOK teachers, all members of the school principal and teacher population were used as respondents..

\section{Sampling Procedures}

Determining the sample of teachers using the total sampling technique (Hickson C, Robinson D, Berg S, 2012), (Hardman, 2008) on the basis that all vocational school physical education teachers in Batubara District already understand the 2013 curriculum. The sample of students used a purposive sampling technique on the basis that students who already understood the 
questionnaire filling were class $\mathrm{XI}$ students.

Table 3. Determination of the number of samples from the student population

\begin{tabular}{cccc}
\hline Total & \multicolumn{3}{c}{ Error level } \\
\cline { 2 - 4 } $\begin{array}{c}\text { Population } \\
(\mathbf{N})\end{array}$ & $1 \%$ & $5 \%$ & $10 \%$ \\
\hline 2200 & 501 & 301 & 241 \\
\hline
\end{tabular}

\section{Design or Data Analysis}

Data obtained from the results of the analysis, then given consideration (judgments) regarding compliance with existing standards. Suggestions and recommendations given are adjusted to data that have not been fulfilled by looking at the obstacles / constraints that are still encountered. The following is a chart of the results of the evaluation and the giving of consideration to the evaluation result data:

Table 4. Chart of Statements and Data on the Evaluation Results of the Stake Countenance

Model on the Implementation of the 2013 Curriculum

\begin{tabular}{|c|c|c|c|c|c|}
\hline $\begin{array}{c}\text { Rational } \\
\text { e }\end{array}$ & Intents & $\begin{array}{c}\text { Observ } \\
\text { ations }\end{array}$ & & $\begin{array}{c}\text { Stand } \\
\text { ards }\end{array}$ & $\begin{array}{c}\text { Judgeme } \\
\text { nts }\end{array}$ \\
\hline \multirow{8}{*}{$\begin{array}{c}\text { Compari } \\
\text { ng } \\
\text { Conditio } \\
\text { ns in the } \\
\text { field the } \\
\text { standard } \\
\text { with }\end{array}$} & $\begin{array}{l}\text { Students } \\
\text { condition }\end{array}$ & $93,4 \%$ & \multirow{5}{*}{$\begin{array}{l}\text { Antec } \\
\text { edent }\end{array}$} & $100 \%$ & $\begin{array}{c}\text { Remainin } \\
\mathrm{g}\end{array}$ \\
\hline & $\begin{array}{c}\text { Teachers } \\
\text { Condition }\end{array}$ & $75 \%$ & & $100 \%$ & $\underset{\mathrm{g}}{\text { Remainin }}$ \\
\hline & $\begin{array}{l}\text { Conditio } \\
\mathrm{ns} \\
\text { infrastru } \\
\text { cture }\end{array}$ & $69,3 \%$ & & $100 \%$ & $\begin{array}{c}\text { Remainin } \\
\mathrm{g}\end{array}$ \\
\hline & $\begin{array}{l}\text { Understa } \\
\text { nding Of } \\
\text { The } \\
\text { Curricul } \\
\text { um }\end{array}$ & $80 \%$ & & $100 \%$ & $\begin{array}{c}\text { Remainin } \\
\mathrm{g}\end{array}$ \\
\hline & $\begin{array}{l}\text { Planning } \\
\text { of } \\
\text { learning }\end{array}$ & $75 \%$ & & $100 \%$ & $\begin{array}{l}\text { yet } \\
\text { fulfilled }\end{array}$ \\
\hline & $\begin{array}{l}\text { process } \\
\text { the } \\
\text { learning }\end{array}$ & $95 \%$ & \multirow[b]{2}{*}{$\begin{array}{l}\text { Trans } \\
\text { action }\end{array}$} & $100 \%$ & $\begin{array}{c}\text { Remainin } \\
\mathrm{g}\end{array}$ \\
\hline & $\begin{array}{l}\text { Impleme } \\
\text { ntation } \\
\text { authenti } \\
\text { c } \\
\text { assessm } \\
\text { ent }\end{array}$ & $90 \%$ & & $100 \%$ & $\begin{array}{c}\text { Remainin } \\
\mathrm{g}\end{array}$ \\
\hline & $\begin{array}{l}\text { assessm } \\
\text { ent } \\
\text { results } \\
\text { authenti } \\
\text { c }\end{array}$ & $82,5 \%$ & $\begin{array}{c}\text { Outco } \\
\text { mes }\end{array}$ & $100 \%$ & $\begin{array}{l}\text { Already } \\
\text { fulfilled }\end{array}$ \\
\hline
\end{tabular}

1. Introductory Phase(antecedent)

a. Student Condition Student

condition consists of readiness and activeness in learning. The condition of students who were in the very good and good category was $93.4 \%$ and $6.6 \%$, this shows that many students are already active in learning PJOK in the field, students use the internet in terms of learning preparation and looking for material sports movements that are carried out and tried. movements to be studied and look for material other than those taught by the teacher, in line with this $\mathrm{Al}$ Bahra (Hermansyah 2012: 2) explains that "Information is data that has been processed into a form that is more meaningful and useful for recipients to make present and future decisions. ". From the results of the discussion with the class XI teacher of PJOK at the time of observation of learning, the condition of class XI students according to the teacher was the skill of class XI students in carrying out activities in learning. The material in the book requires students to be able and able to carry out the basic movements of learning PJOK. In this case, the curriculum is structured to provide various opportunities for students to learn. Students are given the opportunity to improve their abilities. The term curriculum is basically not only limited to a number of subjects, but also includes all learning experiences that affect personal development (Hernawan, 2011).

Looking at the description of the evaluation results, the consideration given is that the teacher should motivate students to study hard and look for material other than what the teacher provides either through reading material but also with sports equipment that has been modified according to or the same as the actual use of the equipment (Hetland KM, Strand B, 2010), (Napper-Owen G, Marston R, Van Valkenburg P, Afeman H, Brewer J, 2008). Teachers are expected to make innovations so that students' desire to learn can increase, teachers can give assignments related to subject matter by taking teacher textbooks or using PJOK books, for example assignments to make a series of basic sports movements, analyze parts of a series of sports movements, and other. In terms of 
active learning in class, so that students actively ask and answer during the learning process, teachers can motivate students to be active by using various ways, for example giving awards or prizes for active students.

\section{b. Teacher conditions}

Teacher conditions consist of academic qualifications, pedagogical competence, personality competence, social competence, and professional competence. The questionnaire for teacher conditions was filled in by the principal directly as the superior, namely assessing the competence of the K13 implementing teacher. The conditions of teachers in the very good and good categories were $75 \%$ and as many as $25 \%$ were in the poor and very poor category.

\section{1) Academic Qualification}

Teacher conditions related to academic qualifications, there are still teachers who have not met the qualifications of S1 educators, namely there are still those who have no qualifications related to PJOK / Physical Education, are currently pursuing further studies for S1 PJOK qualifications (from FIK / S1 education). However, there are efforts that have been made by the teacher to improve the qualifications of the teaching staff by taking a continuing learning program for linearity and meeting the undergraduate academic qualifications of PJOK (S1). The consideration given was that schools could increase cooperation with the education office, local government, and the LPTKs to improve the qualifications of teaching staff.

\section{2) Pedagogic Competence}

Conditions related to academic competence, which are still at good but low percentages, are that there are still teachers who do not understand the characteristics of students related to physical, intellectual, socioemotional, moral, spiritual, and social background aspects, then determining the appropriate learning experience to achieve the learning objectives that are taught is still low, in terms of arranging learning materials correctly according to the chosen approach and according to the characteristics of students it is still low, teachers are also still low in terms of making transactional decisions in learning that are in accordance with the situation developing in learning, and teachers are also still low in evaluating learning processes and outcomes. Considerations are given, namely optimization in terms of conducting training in schools related to the implementation of the 2013 curriculum, especially related to understanding the characteristics of children and evaluating learning and learning outcomes (Sanders S, McCrum D, 1999), (Penney, D., 2001). In this regard, the Education Office / technical implementation unit should be able to increase the knowledge / knowledge / skills of teachers in developing syllabus / curriculum by training / workshops in collaboration with experts (lecturers from LPTK, from education and training organizers, and so on). Teachers should be observant in analyzing problems that arise in learning. Then try to find a solution to the most realistic problems that can be applied directly in the classroom learning. Of course, a lot of insight is needed. Teachers must be diligent in reviewing research results / findings that have been published in research journals / reports.

\section{3) Personality competence Personality}

competence all statements have met the standard with a score range of 3 (good) but from all statements there is one statement that is the lowest of the whole, namely behaving in accordance with the code of ethics of the teaching profession, namely with a percentage of $63 \%$ in a good position but low. The overall condition of the teacher on average is met with a scale of 3 (good). From this data, the teacher actually fulfilled every agenda well, but none of them met it until the score was very good. The consideration given to improve the above is by optimizing the motivation and leadership / managerial role of the principal. The principal motivates the teachers to be able to behave properly like a teacher, in order to increase the teacher's personality competence. The principal also activates teachers to be able to collaborate with peers to improve the quality and role of teachers in learning. 


\section{4) Social Competence The}

the condition of teachers related to social competence which is largely unfulfilled is related to indicators of being inclusive, acting objectively, and not discriminating due to considerations of gender, religion, race, physical condition, family background, and socioeconomic status with sub indicators. Do not discriminate against students, peers, parents of students and the school environment because of differences in religion, ethnicity, gender, family background, and socio-economic status. The most common condition is the 2 scale range (less), so that In fact, most of the teachers have met these standards, only a small proportion have not. The consideration given to this is to increase the participation of teachers in society with the motivation that the importance of teachers being able to be fair to all their students, must bring benefits to others and provide equal treatment to all students. For example, when learning activities all students must receive the same learning experience, the teacher must not allow students who do not receive learning experiences at school, and so on.

\section{5) Professional Competence}

The average professional competency condition is in the good category related to mastering the material, structure, concept, and scientific mindset that supports the subject being taught. Related to this, obtaining the lowest score with the category of low scores, explaining the dimensions of human anatomy, structurally and its function must be carried out by PJOK teachers, because the anatomy of motion is related to the basic motion of sports. The consideration for improving teacher performance related to unfulfilled professional competences is the provision of selfdevelopment programs held by the related education offices in collaboration with the Education Quality Assurance Agency (LPMP) and the LPTK. Self-development program by holding various learning innovation competitions / educational teaching aids competitions which are participated by all teachers starting from the cluster level so that teachers are motivated to participate. Teachers must also be active in self-development related to their quality by attending seminars / workshops / training.

A good curriculum will run well if it is processed by good teachers. Teachers play an important role in improving the quality of education. Quality education will only be achieved by qualified and professional teachers who have sufficient competence. Furthermore, Muhammad Nur Wangid (2014: 29) explains the important role of teachers in implementing the curriculum. Facing the new curriculum requires teachers with the most experience in teaching, especially those with teaching experience in a variety of different curricula. Teachers who are committed to innovation deserve to be in the classroom with the new curriculum. Therefore, the knowledge of teachers for professional development needs to be improved with various training / workshops. The obstacle that often arises is that not all teachers can be reached by this training. The solution is often done by holding one-day workshops provided by experts with the lecture method being the dominant pedagogical strategy. Schools can represent the most innovative teachers to take part in the training, then to be able to pass on the knowledge that has been obtained to other teacher friends in schools that have not been reached by the training.

Oemar Hamalik (2011: 242) added that the principal also has the task of carrying out administration, management, development, supervision, and professional services for the implementation of learning activities. The principal is obliged to carry out supervision and development of teacher performance so that the quality and competence of teachers is maintained and has increased.

In an effort to make the implementation of the 2013 curriculum a success, Asiyah (2014: 421) adds that it is important to increase the exemplary noble character and competence of educators. The 2013 curriculum has a goal in terms of forming the noble character of students. Educators as the spearhead for the formation of the personality and character of students can instill noble morals through habituation and 
the application of noble morals. If you want students to have noble characters according to the ideals and goals of the 2013 curriculum, then the teacher must be able to set an example of how to have noble character.

\section{c. Infrastructure Facilities and infrastructure}

are in good condition on average. There are some parts that have a low percentage, such as the conditions for classrooms, some are still in poor condition. There are several items in the questionnaire that show a low percentage in the study room / class room indicators such as the function of the classroom as a place for theoretical learning activities, practices that do not require special equipment, or practice with special tools that are easily presented with insufficient conditions, then the minimum area ratio class $2 \mathrm{M}^{2} /$ student, for study groups with students less than 15 the minimum class room is $30 \mathrm{M}^{2}$, while the width is $5 \mathrm{M}$ in a poor condition. Cabinets and trash cans are also in poor condition.

For schools, the average library space indicator is good, but there are two statements in the questionnaire that show a low percentage, such as statements regarding 15 reading chairs / school, then 1 electric socket / room. Librarians must also be innovative and creative in increasing the number of facilities for chairs by submitting proposals to the school infrastructure sector to provide appropriate chairs and electrical sockets so that the library can be used optimally.

The condition of the facilities and infrastructure related to the place to play / exercise is all good, only a small proportion of them do not physically have a special field for sports activities. As illustrated in the statement item where to play / exercise is placed in a place that does not interfere with the learning process in the classroom, and the place to play / exercise is not used for parking, which is in a good percentage but is in a low position, Consideration given: schools can cooperate with the education office for the procurement of a field that can be used for sports activities and that can be used at any time. So that the function of tools / media for sports such as balls and others can be optimized. Schools that physically have a sports field for tools / media must make use of various tools / media for learning as much as possible. Schools can hold simple competitions to increase student interest and achievement from sports. Existing equipment must be inventoried and maintained to make it durable. Asiyah (2014: 716) in his research found that the classroom conditions of the learning environment have a great impact on student learning and motivation, including motivation to actively participate in academic activities; can affect the personal behavior and attendance of students at school. This study concludes by recommending that government and other education stakeholders should give priority attention to creating a positive learning environment in schools for student learning success and academic development.

\section{d. Teachers 'Understanding of the Curriculum}

Teachers' understanding of the 2013 curriculum is good. However, for indicators related to choosing learning activities that are in accordance with the material in the lesson plan, conducting an analysis of teaching materials to determine the suitability of SKL, $\mathrm{KI}, \mathrm{KD}$ between teacher books and student books. Knowing the functional relationship between teacher manuals and textbooks in the learning process, and having teacher handbooks, most teachers are still in range 3 (good) but are still in a low position. The unfulfilled indicators are still at a good but low score. From the results of extracting further information, this is due to the limitations of books related to old books and time constraints due to the large number of teacher administrations that must be done, especially making lesson plans and assessments.

The consideration given is to increase the Subject Teacher Deliberation (MGMP) activities in analyzing teaching materials together, developing teaching materials, and developing syllabus according to the conditions and characteristics of students and applying them according to what has been discussed. Of course, the MGMP activities must be accompanied by related parties, in this case the school principal / school supervisor. 
You can also bring in competent sources as sources.

Teachers' understanding of the 2013 curriculum can also be improved by providing technical guidebooks for curriculum implementation that are prepared based on the understanding that the principal or school leaders pay special attention to the implementation of the 2013 curriculum. It is possible that the teacher provides material that is not in accordance with the material contained in student textbooks, so that with more attention can directly assist in the practice of learning so that it can be carried out very well. This is like what has been used by kindergarten teachers in Greece to help increase teachers' understanding of the application of the new curriculum (Sofou \& Tsafos, 2009: 419).

In terms of completeness of curriculum documents and learning administration, it can be improved by optimizing the role of leadership and supervision of the principal. The principal can also reward the teacher's performance. Various competitions for outstanding teachers can also be held every semester.

\section{e. Learning}

planning The conditions for the lesson planning (RPP) prepared by the teacher are generally good. However, there are still deficiencies in some parts. The average score received is 3 (good), from several statement items, some of them are at a good percentage but low in the statement items of conformity with learning objectives with a percentage of $68.75 \%$, conformity to the scientific approach with a percentage of $68.8 \%$, suitability of activities with the scientific approach with a percentage of $67.5 \%$, and suitability of scoring guidelines with questions with a percentage of $65 \%$.

Some teachers arrange learning materials only the main material. Even though the material should have been adjusted to the learning objectives and adjusted to the scientific approach and learning activities were also adjusted to the scientific approach and also the scoring guidelines were also adjusted to the questions made. Based on Permendikbud Number 103 of 2014, the part of the learning scenario is in the form of a description of the learning activities in the syllabus in a more operational form in the form of a scientific approach adapted to the conditions of students and educational units including the use of media, tools, sports facilities and infrastructure and learning resources. In general, the formulation of learning scenarios is appropriate. However, there are still some who have not included in detail the stages of the scientific approach, causing the suitability of the systematic presentation of the material to become less clear.

The consideration given is that teachers are often given training / workshops on the preparation of correct lesson plans and in accordance with the latest Permendikbud. This activity was carried out by inviting direct speakers from academics (lecturers) who had studied this in depth, especially from institutions related to PJOK subjects. School supervisors should also be active in updating information and understanding in teacher administration according to the latest regulations (Luke, M., 2000), (Brunelle, J., 2002).

\section{Process stage (transaction)}

The process stage (transaction) consists of the learning process and the implementation of authentic assessments. The following is a description of each stage:

At this stage the learning process is divided into 3 parts, namely preliminary activities, core activities, and closing activities. Preliminary activities consist of perceptions and motivation as well as delivery of competencies and activity plans. In the apperception section, the motivation in the statement points demonstrates something related to the teaching material showing a percentage of $56.25 \%$ and checking the initial behavior (entry behavior) of $57.5 \%$, this statement shows a lack of percentage. Then in the core activities in the statement item the ability to link material with relevant 
knowledge, the development of science and technology and real life shows a percentage of $57.5 \%$, and managing the discussion of learning materials and learning experiences appropriately shows a percentage of $56.25 \%$, this statement shows Inadequate conditions. On the indicator of implementing educational learning strategies in the statement items managing the class (maintaining discipline and class atmosphere) shows a percentage of $57.5 \%$, this percentage still shows a lack of condition. Then the indicators of applying a scientific approach to the statement items facilitate students to try and observe a percentage of $57.5 \%$ and give questions to students for reasoning (logical and systematic thinking processes) to get a percentage of $55 \%$, this statement shows that the conditions are lacking. on the three points of the statement.

There are still some teachers in the indicator section of the use of learning resources / media in learning in the statement items showing the skill in using learning media shows a percentage of $55 \%$, this percentage indicates a lack of conditions, then the statement items involving students in the use of learning media show a percentage of $55 \%$ in less condition. In the indicator of the involvement of students in learning in the statement items, it fosters the joy and enthusiasm of students in learning, showing a percentage of $57.5 \%$, this condition indicates a position that is less. In the indicator section for using correct and appropriate language in learning, the statement items using written language that are good and correct get a percentage of $57.5 \%$ with a description of the lack of conditions.In

This observation activity, the core activities include mastery of subject matter, implementing learning strategies, educating, applying a scientific approach, utilizing learning resources / media in learning, involving students in learning, using correct and appropriate language in learning. In terms of mastery of subject matter, the teacher's ability to adapt the material to learning objectives has not been achieved properly. There are even teachers who have not added achievement indicators and materials tailored to the needs of students. Some teachers have also been able to link the material with other relevant knowledge, science and technology developments, and real life.

The learning that has been carried out has allowed the growth of positive habits (nurturant effect). Starting from the habit of lining up before starting learning that instills discipline, praying before starting learning to strengthen spiritual attitudes, scientific-based learning that trains scientific thinking skills, group discussions to develop social attitudes and cooperative / cooperative abilities, and many others. (Syed, KSA, Jani, J., 2010), (Payne, PG, 2003).

The application of the scientific approach to learning has not looked completely good in accordance with the 2013 curriculum syllabus and guidebook that has been formulated in the RPP. Teachers and students have started to get used to carrying out scientific-based learning stages, namely observing, questioning, gathering information, reasoning / analyzing, and communicating. The activities of trying and observing are still lacking because usually the teacher does not stimulate students with questions that can arouse curiosity about a demonstration at the beginning. Students in terms of observing a display / impression / demonstration by the teacher are still low. However, in line with trying activities, it is still dominated by teachers not by students.

The application of scientific-based learning has been carried out well according to the syllabus. The teacher has presented learning according to the material with one lesson. Learning that contains integrated characteristics according to Suyanto \& Asep Jihad (2013: 254-255) has the following characteristics: 1) student-centered, 2) provides direct experience, 3) segregation of subjects that are not very clear, 4) presents the concept of various subjects, 5) being flexible, 6) learning outcomes according to students' interests and needs, 7) using the principles of learning while playing and having fun. Most of the classes have carried out studentcentered learning, nuanced active and fun by providing direct experiences. Even for PJOK 
teachers, there are challenges in presenting active and fun learning with children whose desire to learn tends to the sports they are interested in. Usually the learning time in the core class exceeds the specified time allocation because sometimes the teacher has to direct students who are not yet able to serve well on volleyball. Meanwhile, for the flexibility nature of the various subject matter, sometimes the material association is limited to using reading, not based on direct experience.

In the use of learning resources / media in learning, most teachers have shown skills in the use of learning resources / learning media. The main learning resources used are from student books and other learning resources (LCD projector / video). In the closing activity, the teacher reflects on the learning being carried out. This is done by asking students' impressions / messages about the learning that day whether it is fun / not, useful / not. The teacher also asks questions that students do not understand usually by giving oral or written tests which are then carried out a discussion about the absorption of the material by the students. The teacher also collects student work as portfolio material. Follow-up to (Harris, KC, Kuramoto, LK, Schulzer, M., Retallack, JE, 2009), (Cowie, B., 2005), (Dixon, H., Haigh, M., 2009), the next activity is usually students are asked to learn sports movements for the next meeting.

The considerations given to the implementation of learning are:

\section{Preliminary activity stage}

To increase student motivation, the teacher should prepare props / media that can be demonstrated in the form of pictures and videos. The displayed image should be easy to see and attractive. The video that is displayed is also attractive and clear in both image and sound. Sometimes the display of images in the student book looks modest, so the teacher can add the pictures / videos that have been prepared in advance. Teachers as much as possible convey the benefits of learning materials so that students' interest and motivation towards learning increases, especially in terms of learning sequences at the trying and observing stages in order to arouse curiosity about the subject matter. And the teacher does not forget to check the students' initial behavior so that it can be used as assessment material.

\section{Stage of core activities.The}

a teacher should prepare learning materials related to subject matter other than those in the teacher / student books so that the discussion of the material is more in-depth. The teacher should facilitate the exploration, elaboration, and confirmation components that are presented using interesting learning resources / learning media, so that learning becomes active and fun, especially using science and technology to make it more innovative and interesting, then raises questions that can train students' reasoning so that students can think logically, always involve students in the use of learning media or more inviting students to practice directly in learning and use good language so that joy and enthusiasm can be created during learning by students.

\section{Closing learning}

Strengthening needs to be done especially in relation to strengthening spiritual attitudes and social attitudes. Enrichment assignments can be given for homework as a follow-up to learning. If possible, hold a competition between students at the end of the school year in order to further foster student interest so that they can develop students' basic abilities.

The implementation of authentic assessments has been carried out well even though the teacher feels too heavy in the process. All indicators have been carried out well, the percentage obtained from each statement is a good average, starting from conducting an assessment at the end of the learning process, having a document of the results of the assessment, the instruments used according to the rules, managing the time in the assessment, carrying out the skills assessment, having documents assessment of 
skills, having a document of learning outcomes, having a document of the collection of student learning outcomes, carrying out attitude assessments in each lesson, having documents of attitudes and results of attitudes, and reporting the value of learning outcomes is carried out in good and very good conditions.

As for the consideration of fostering teacher performance, training on assessment instruments should often be carried out to hone teachers' abilities in terms of evaluation. The training that is carried out at the same time can add to and improve the results of the assessment. Improving teacher performance in terms of authentic assessment processes can be improved, one of which is by holding teacher working group (KKG) activities to further improve authentic assessment. KKG is a collaborative activity for teachers so that they can learn from each other between teachers. One of the obstacles with the KKG activities is how the KKG activities can be carried out without having to leave learning hours at school. Usually teachers choose the KKG schedule on days that are not very effective, weekends. Another strategy that can be taken is that schools can send teacher representatives to attend KKG between schools / or by sending teachers to study in other schools that are considered more advanced. This is in accordance with Wiles (2009: 124), that schools can send teacher group representatives to other schools (in other areas) or conferences to see something new that is usually well received by individuals who rarely leave their class.

\section{Results stage (Outcomes)}

The results stage is the authentic assessment results obtained from observations of the student's score list. The results of authentic assessments in the form of values on the aspects of attitudes, skills, and knowledge have also met the standards of the government. For the minimum attitude score of $\mathrm{B}$ has been met in all schools. The value of the skills and knowledge aspects with a standard value of 2.67 (B-) has also been fulfilled.
After descriptions of each stage in curriculum implementation are carried out, and comparisons are made between the expectations according to the standards and the actual implementation conditions in the field, then look at the gaps between the vertical stages. The following is a process chart for the description of the stake model data:

Table 5. Data Processing Chart Description Model Stake

\begin{tabular}{|c|c|c|c|}
\hline $\begin{array}{l}\text { Expected state } \\
\text { (intended) }\end{array}$ & & & $\begin{array}{l}\text { Actual } \\
\text { Conditions } \\
\text { (observed) }\end{array}$ \\
\hline $\begin{array}{l}\text { Antecedent } \\
\text { Condition of } \\
\text { students, Condition } \\
\text { of teachers, } \\
\text { Understanding of } \\
\text { teachers of } \\
\text { curriculum, } \\
\text { Conditions of } \\
\text { infrastructure } \\
\text { Learning planning }\end{array}$ & $100 \%$ & Conformity & $78,54 \%$ \\
\hline Gap & & & Gaps in the \\
\hline $\begin{array}{l}\text { Transaction } \\
\text { Learning process, } \\
\text { Implementation } \\
\text { ofAuthentic } \\
\text { assessments }\end{array}$ & $100 \%$ & Conformity & $92,5 \%$ \\
\hline Gap & & & Gaps in the \\
\hline $\begin{array}{l}\text { Outcomes } \\
\text { Hasil penilaian }\end{array}$ & $100 \%$ & Kesesuaian & $82,5 \%$ \\
\hline
\end{tabular}

\section{RESULTS}

Data obtained in this study were divided into three parts, namely the antecedent, the process (transaction), and the outcome (outcomes). At each stage, it will be seen (horizontally) the congruence between the planning (intents) and the implementation result data obtained from field observations. If there is a discrepancy, considerations / suggestions / input are given to the implementation of the 2013 Curriculum according to the conditions in the field. Furthermore, it will also look at the gaps that exist at each stage. 
Table 6. The result of the evaluation of curriculum implementation in 2013

\begin{tabular}{|c|c|c|c|c|c|}
\hline \multirow[t]{2}{*}{$\begin{array}{l}\text { Tahap } \\
\text { an }\end{array}$} & \multirow[t]{2}{*}{$\begin{array}{l}\text { ASPE } \\
\text { K }\end{array}$} & \multicolumn{2}{|c|}{$\begin{array}{l}\text { Description } \\
\text { matrix }\end{array}$} & \multicolumn{2}{|c|}{$\begin{array}{l}\text { Judgment } \\
\text { matrix }\end{array}$} \\
\hline & & Intents & $\begin{array}{l}\text { Obser } \\
\text { vation } \\
\text { s }\end{array}$ & $\begin{array}{l}\text { Stan } \\
\text { dard } \\
S\end{array}$ & $\begin{array}{l}\text { Judg } \\
\text { ments }\end{array}$ \\
\hline \multirow[t]{5}{*}{$\begin{array}{l}\text { Penda } \\
\text { huluan } \\
\text { (Antec } \\
\text { edent) }\end{array}$} & $\begin{array}{l}\text { Kondis } \\
\text { i siswa }\end{array}$ & $\begin{array}{l}\text { Kesiapa } \\
\mathrm{n} \\
\text { mengiku } \\
\text { ti } \\
\text { pembela } \\
\text { jaran } \\
\text { dan } \\
\text { keaktifa } \\
\mathrm{n} \\
\text { mengiku } \\
\text { ti } \\
\text { pembela } \\
\text { jaran }\end{array}$ & $93,4 \%$ & $\begin{array}{l}100 \\
\%\end{array}$ & $\begin{array}{l}\text { Ada } \\
\text { Pertim } \\
\text { banga } \\
n\end{array}$ \\
\hline & $\begin{array}{l}\text { Kondis } \\
\text { i guru }\end{array}$ & $\begin{array}{l}\text { Kualifik } \\
\text { asi } \\
\text { akademi } \\
\text { k } \\
\text { Kompet } \\
\text { ensi } \\
\text { pedagog } \\
\text { ik } \\
\text { Kompet } \\
\text { ensi } \\
\text { kepribad } \\
\text { ian } \\
\text { Kompet } \\
\text { ensi } \\
\text { sosial } \\
\text { Kompet } \\
\text { ensi } \\
\text { profesio } \\
\text { nal }\end{array}$ & $75 \%$ & $\begin{array}{l}100 \\
\%\end{array}$ & $\begin{array}{l}\text { Ada } \\
\text { Pertim } \\
\text { banga } \\
n\end{array}$ \\
\hline & $\begin{array}{l}\text { Kondis } \\
\text { i } \\
\text { sarana } \\
\text { prasar } \\
\text { ana }\end{array}$ & $\begin{array}{l}\text { Ruang } \\
\text { kelas } \\
\text { Perpusta } \\
\text { kaan } \\
\text { Tempat } \\
\text { bermain/ } \\
\text { olahraga }\end{array}$ & $69,3 \%$ & $\begin{array}{l}100 \\
\%\end{array}$ & $\begin{array}{l}\text { Ada } \\
\text { pertim } \\
\text { banga } \\
n\end{array}$ \\
\hline & $\begin{array}{l}\text { Pemah } \\
\text { aman } \\
\text { terhad } \\
\text { ap } \\
\text { Kurik } \\
\text { ulum } \\
2013\end{array}$ & $\begin{array}{l}\text { Pemaha } \\
\text { man } \\
\text { terhadap } \\
\text { Kurikulu } \\
\text { m } \\
2013\end{array}$ & $80 \%$ & $\begin{array}{l}100 \\
\%\end{array}$ & $\begin{array}{l}\text { Ada } \\
\text { Pertim } \\
\text { banga } \\
\mathrm{n}\end{array}$ \\
\hline & $\begin{array}{l}\text { Perenc } \\
\text { anaan } \\
\text { pembe } \\
\text { lajara } \\
\text { n }\end{array}$ & $\begin{array}{l}\text { Perenca } \\
\text { naan } \\
\text { pembela } \\
\text { jaran }\end{array}$ & $75 \%$ & $\begin{array}{l}100 \\
\%\end{array}$ & $\begin{array}{l}\text { Ada } \\
\text { Pertim } \\
\text { banga } \\
n\end{array}$ \\
\hline Rata-rata & & & $\begin{array}{l}78,54 \\
\%\end{array}$ & $\begin{array}{l}100 \\
\%\end{array}$ & Ada \\
\hline
\end{tabular}

\begin{tabular}{|c|c|c|c|c|c|}
\hline & & & & & $\begin{array}{l}\text { Pertim } \\
\text { banga } \\
n\end{array}$ \\
\hline \multirow[t]{2}{*}{$\begin{array}{l}\text { Proses } \\
\text { (Trans } \\
\text { action) }\end{array}$} & $\begin{array}{l}\text { Pelaks } \\
\text { anaan } \\
\text { pembe } \\
\text { lajara } \\
\text { n }\end{array}$ & $\begin{array}{l}\text { Pelaksan } \\
\text { aan } \\
\text { pembela } \\
\text { jaran }\end{array}$ & $95 \%$ & $\begin{array}{l}100 \\
\%\end{array}$ & $\begin{array}{l}\text { Ada } \\
\text { Pertim } \\
\text { banga } \\
\mathrm{n}\end{array}$ \\
\hline & $\begin{array}{l}\text { Pelaks } \\
\text { anaan } \\
\text { penilai } \\
\text { an } \\
\text { autenti } \\
\text { k }\end{array}$ & $\begin{array}{l}\text { Pelaksan } \\
\text { aan } \\
\text { Penilaia } \\
\text { n } \\
\text { autentik }\end{array}$ & $90 \%$ & $\begin{array}{l}100 \\
\%\end{array}$ & $\begin{array}{l}\text { Ada } \\
\text { Pertim } \\
\text { banga } \\
\mathrm{n}\end{array}$ \\
\hline Rata-rata & & & $92,5 \%$ & $\begin{array}{l}100 \\
\%\end{array}$ & $\begin{array}{l}\text { Ada } \\
\text { Pertim } \\
\text { banga } \\
\mathrm{n}\end{array}$ \\
\hline $\begin{array}{l}\text { Hasil } \\
\text { (outco } \\
\text { mes) }\end{array}$ & $\begin{array}{l}\text { Hasil } \\
\text { penilai } \\
\text { an } \\
\text { autenti } \\
\text { k }\end{array}$ & $\begin{array}{l}\text { Hasil } \\
\text { penilaia } \\
\text { n } \\
\text { autentik }\end{array}$ & $82,5 \%$ & $\begin{array}{l}100 \\
\%\end{array}$ & $\begin{array}{l}\text { Tidak } \\
\text { Ada } \\
\text { Pertim } \\
\text { banga } \\
\mathrm{n}\end{array}$ \\
\hline Rata-rata & & & $82,5 \%$ & $\begin{array}{l}100 \\
\%\end{array}$ & $\begin{array}{l}\text { Ada } \\
\text { Pertim } \\
\text { banga } \\
n\end{array}$ \\
\hline
\end{tabular}

From the data presentation in the table above, an analysis is carried out to find the suitability between the implementation of the 2013 Curriculum which is expected to be in accordance with the standards observed in each -Each stage.

1. Preliminary stage

a. Student conditions Student

conditions include student readiness in participating in learning and student activeness in learning. Indicators of student readiness in participating in learning consist of 5 sub indicators (with 16 statement items), namely a) enthusiasm in following lessons; b) Learning equipment; c) Regular learning patterns; d) Looking for material outside of study hours; and e) Discipline. Indicators for learning activeness consist of 3 sub indicators (12 statement items), namely: a) taking the lesson seriously; b) Active in learning; and c) Orderly during learning. The condition of students who were categorized as very good and good was $93.4 \%$. The condition of students who were categorized as less was 
$6.6 \%$. Student conditions related to student readiness in participating in learning and student activeness in learning were included in the very good category, namely $40.9 \%$. And that is included in the good category, namely $52.5 \%$. As well as those included in the less category, namely $6.6 \%$.

\section{b. Teacher conditions Teacher}

conditions include academic qualifications, pedagogical competence, personality competence, social competence, and professional competence. The condition of the teachers as a whole which is in the very good category is $75 \%$, and in the poor category is $25 \%$.

\section{c. Conditions of infrastructure Facilities and infrastructure}

conditions as a whole are in the very good category of $38.5 \%$, the good category is $30.8 \%$, the poor category is $23.1 \%$, and the very poor category is $7.6 \%$. learning rooms / classrooms, library conditions, and a place to play / exercise

d. Teachers' understanding of the 2013 curriculum

Conditions related to curriculum understanding consist of 4 indicators, namely 1) Reviewing the curriculum / syllabus; 2) Reviewing Teacher's and student's books; 3) compiling the ideal RPP; and 4) have complete curriculum documents and teaching materials. As many as $30 \%$ are in the very good category, $50 \%$ are in the good category, $20 \%$ are in the poor category. $80 \%$ of the data in the good category.

\section{e. Learning planning Learning}

planning consists of 9 sub indicators, namely 1) the identity of the subjects; 2) formulation of indicators; 3 ) formulation of learning objectives; 4) selection of teaching materials; 5) selection of learning resources; 6) selection of learning media; 7) learning model; 8) learning scenarios; and 9) assessment. The learning planning conditions for data were categorized as very good as much as $50 \%$, as much as $25 \%$ were in the good category, $25 \%$ were in the poor category, and $0 \%$ were in the very poor category. $75 \%$ of the data in the good category.

\section{Process stage (transaction)}

The process stage consists of implementing learning and implementing authentic assessments. The learning process consists of 9 indicators, namely a) Conducting perception and motivation; b) Describe competencies and plan activities; c) Mastering the material being taught; d) Implementing educational learning strategies; e) Apply approach scientific; f) Utilizing learning resources / media in learning; g) Trigger / maintain the involvement of students in learning; h) Ending learning effectively; and i) Using correct and appropriate language in learning. Conditions related to the implementation of learning obtained data in the very good category $50 \%, 45 \%$ good category, and $5 \%$ less category. $95 \%$ of the data in the good category.

Implementation of authentic assessment consists of 4 indicators, namely a) Assessment of mastery of knowledge, skills and attitudes by the teacher; b) Assessment by students; c) Processing the value of learning outcomes; and Reporting the value of learning outcomes. Conditions related to the implementation of authentic assessments were in the very good category of 55\%, 35\% in good category, $10 \%$ in poor category. The data in the good category was $85 \%$.

\section{Results stage (Outcomes)}

The results stage is the result of authentic assessment which includes the value aspects of knowledge, skills, and attitudes. Data from the authentic assessment results are in the very good category of $30 \%$, in the good category $70 \%$, in the poor category at $0 \%$, and in the very poor category at $0 \%$. 


\section{CONCLUSION}

The results of the evaluation research on the implementation of this curriculum show that the implementation of the 2013 SMK curriculum in Batubara district uses the evaluation stakeholder model, starting from thestages, antecedent namely 5 (five) indicators, namely student conditions, teacher conditions, infrastructure conditions, learning planning conditions, the condition of the teacher's understanding of the curriculum shows a good average percentage of $78.54 \%$, thestages transaction are 2 (two) indicators, namely the implementation of learning and the implementation of authentic assessment shows an average percentage of $92.5 \%$ and the outcomes average of the value described is $82.5 \%$. All aspects in each stage have not been fulfilled (100\%) according to the standard. However, it can be seen that several aspects in each stage have been categorized as good or even very good. Therefore, the findings from this study are expected to be used as material to improve the performance of all parties in implementing the 2013 curriculum. In the end, the implementation of the 2013 curriculum can run according to the standards set by the government.

\section{REFERENCES}

Asiyai, R. (2014). Students'perception of the condition of their classroom physical learning environment and its impact on their learning and motivation. College Student Journal. Winter2014, 48(4),716726.

Brunelle, J. (2002). L'intervention en activité physique et sportive: un point de vue sur la recherché nord-américaine. Avante, $8(2), 1-13$

Cowie, B. (2005), Pupil commentary on assessment for learning. Curriculum Journal, 16(2), 137-151.

Dixon, H., Haigh, M. (2009), Changing mathematics teachers conceptions of assessment and feedback. Teacher Development: An International Journal of Teachers Professional Development, 13(2), 173-186.

Hamalik, O. (2008). Manajemen pengembangan kurikulum. Bandung: Remaja Rosdakarya.

Hardman K (2013). Global issues in physical education: Worldwide physical education survey III findings. Intl. J. Phys. Educ. 50(3), 15-28.

Hardman K (2008). The situation of physical education in schools: A European perspective. Hum. Movement 9(1), 5-18.

Harris, K.C., Kuramoto, L.K., Schulzer, M., Retallack, J.E. (2009), Effect of Schoolbased physical activity interventions on body mass index in children: Ametaanalysis. Canadian Medical Association Journal, 180(7), 719-180.

Hetland KM, Strand B (2010). A descriptive analysis of undergraduate PETE programs in the central district. ICHPER-SD J. Res. In: Health, Phys. Educ. Recreation Sport Dance. 5(1), 3-9.

Hickson C, Robinson D, Berg S (2012). Active in the North community physical activity programming in Canada. Intl. J. Phys. Educ. 49(2), 16-30.

Luke, M. (2000). Physical and health education curriculum: Cross-Canada perspectives. CAHPERD , 66(2), 4-12.

Majid, A. (2014). Implementasi Kurikulum 2013 Kajian Teoritis dan Praktis.Bandung: Interes Media.

Mardapi, D. (2008). Teknik penyusunan tes dan nontes. Yogyakarta: MitraCendikia.

Moleong, Lexy. 2007 . Metodologi Penelitian Kualitatif. Bandung : PT Remaja Rosdakarya.

Nasution. (2014). Asas-asas kurikulum. Jakarta: PT. Bumi Aksara

Napper-Owen G, Marston R, Van Volkinburg P, Afeman H, Brewer J (2008). What constitutes a highly qualified physical education teacher. J. Phys. Educ. Recreation Dance. 79(8), 26-30.

Payne, P.G. (2003), The technics of environmental education. Environmental Education Research, 9(4), 525-541.

enney, D. (2001). The revision and initial implementation of the National curriculum for physical education in 
England. Bulletin of Physical Education, 37(2), 93-134

Sofou, E. \& Tsafos, V. (2009). Preschool teachers' understandings of the nationalpreschool curriculum in greece.

Suyanto \& Asep Jihad. (2013). Menjadi guru profesional. Jakarta: Erlangga.

Syed, K.S.A., Jani, J. (2010), Implementation of teaching of physical education (physical fitness). Series Physical Education and Sport/ Science, Movement and Health, 10(2), 294-297.

Wiles, J. (2009). Leading curriculum development. New York: Corwin Press ASAGE Company.

Wangid, M.N. (2014). Guru sebagai kunci pelaksanaan kurikulum 2013. Makalah disajikan dalam Seminar Nasional Pemantapan Implementasi Kurikulum2013 dalam Pendidikan Sekolah Dasar di Universitas Negeri Yogyakarta. 